\title{
Implementasi Sistem Monitoring Kecepatan Angin, Suhu, dan Kelembaban Berbasis Web di Daerah Kepulauan
}

\author{
Rian Anjasmara*, Tonny Suhendra, dan Anton Hekso Yunianto \\ Universitas Maritim Raja Ali Haji, Tanjungpinang, Indonesia \\ "Email: riianofficial@gmail.com
}

\begin{abstract}
Abstrak - Pengukuran suhu, kelembaban, dan kecepatan angin sangat penting untuk dilakukan di pulau sebagai informasi cuaca kepada masyarakat. Sistem monitoring ditambahkan perangkat pengiriman data menggunakan kartu GSM agar dapat ditampilkan datanya ke dalam dashboard platform online. Penelitian ini bertujuan melakukan pengembangan sistem monitoring kecepatan angin, suhu, dan kelembaban berbasis web yang dapat diterapkan di daerah kepulauan, pemantauan data secara realtime yang terkirim ke platform, dan pengukuran konsumsi daya pada perangkat. Metode penelitian ini dilaksanakan dengan melakukan studi literatur, observasi, perancangan, dan pengujian sistem. Pada penelitian ini GSM Shield SIM900 digunakan sebagai perangkat pengiriman data, DHT22 sebagai perangkat sensor suhu dan kelembaban, perangkat anemometer sebagai pembaca kecepatan angin, platform Thingspeak sebagai penampil data, dan micro SD Card sebagai penyimpanan data cadangan. Hasil penelitian didapatkan bahwa pengembangan sistem monitoring suhu, kelembaban, dan kecepatan angin telah berhasil dilakukan dengan pengiriman data menggunaakan GSM yang ditampilkan ke dalam platform Thingspeak. Data yang tidak terkirim ke server diduga karena kualitas sinyal GSM pada saat pengiriman data tidak cukup kuat atau karena adanya timeout. Sistem monitoring ini menghabiskan daya sebesar 0,977 Wh..
\end{abstract}

Kata Kunci : Monitoring, Web, SIM900, Kepulauan.

\section{Pendahuluan}

Faktor cuaca mempengaruhi kegiatan yang dilakukan manusia sehari-hari, sehingga dibutuhkan perangkat monitoring yang memberi informasi cuaca yang dapat diakses dimanapun kita berada. Penelitian yang terkait dengan teknologi pemantauan cuaca antara lain Monitoring Kecepatan Angin berbasis Web [1]. Website adalah salah satu media yang digunakan untuk menampilkan informasi yang biasanya terintegrasi dengan jaringan internet. Data yang dihasilkan dari perangkat monitoring dikirim ke database. Selanjutnya data yang terkirim dapat dipantau menggunakan aplikasi atau platform.

Faktor utama sebuah perangkat dikatakan sebagai online monitoring system adalah pegiriman data. Teknologi pengiriman data yang berkembang saat ini ialah WIFI, GSM, dan Satelit. GSM merupakan teknologi yang tepat digunakan di Kepulauan Riau mengingat bahwa daerah Kepulauan Riau memiliki banyak pulau.

Kepulauan Riau, khususnya daerah pulau 3T memiliki kondisi kurang baik dari sisi telekomunikasi dan ketersediaan listrik, sehingga menjadi permasalahan dalam penerapan peralatan monitoring yang biasanya diletakan di area yang minim ketersedian sumber energi listrik yang kontinu. Pada sistem monitoring dapat disematkan perangkat penyimpan data cadangan seperti yang dilakukan oleh Andoni dan Susanto [2].

Berdasarkan penjelasan yang telah dipaparkan, sistem monitoring kecepatan angin, suhu, dan kelembaban berbasis web di daerah kepulauan perlu dikembangkan guna mengetahui informasi cuaca. Parameter yang harus dicapai dalam pengembangan sistem ini yaitu perangkat monitoring bekerja dengan baik mengirimkan data dan menyimpan data serta dapat memperhitungkan penggunaan energi pada perangkat. Hasil dari penelitian ini berupa perbandingan data pengiriman ke website dan data tersimpan pada micro SD card. Hasil penelitian ini diharapkan dapat dikembangkan lebih lanjut dengan metode, perangkat, dan parameter yang berbeda.

\section{TEORI}

\section{A. Baterai}

Baterai sebagai sumber arus listrik searah (DC) dapat dikelompokkan menjadi dua macam, yaitu baterai elemen kering dan elemen basah. Baterai Lithium Ion merupakan jenis baterai isi ulang yang paling populer untuk peralatan elektronik portabel, karena memiliki salah satu kepadatan energi terbaik, tanpa efek memori, dan mengalami kehilangan isi yang lambat saat tidak digunakan [3].

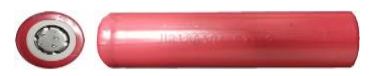

Gambar 1. Baterai Litium Ion UR18650 


\section{B. Daya Listrik}

Daya listrik didefinisikan sebagai laju hantaran energi listrik dalam rangkaian listrik. Satuan SI daya listrik adalah watt yang menyatakan banyaknya tenaga listrik yang mengalir per satuan waktu (joule/detik). Persamaan daya listrik dapat dilihat pada persamaan 1 [4]. Dimana P adalah Daya Listrik (Watt), V adalah Tegangan (Volt), I adalah Arus Listrik (Ampere)

$$
P=V \times I
$$

\section{Arduino}

Arduino merupakan perangkat keras yang bersifat open source dan menggunakan perangkat lunak Arduino Integrated Development Environment (IDE) untuk menulis program yang dibutuhkan. Salah satu board Arduino dapat dilihat pada Gambar 2 [5].

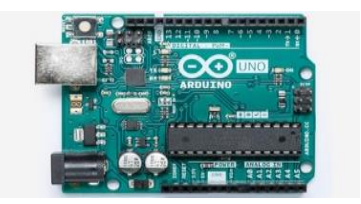

Gambar 2. Arduino Uno Rev.3.

\section{Anemometer}

Anemometer adalah sebuah perangkat yang digunakan untuk mengukur kecepatan angin. Pada saat angin bertiup mengenai balingbaling atau cup yang terdapat pada anemometer akan bergerak. Semakin besar kecepatan angin yang mengenai baling-baling atau cup anemometer maka semakin cepat pula baling-baling atau cup anemometer berputar [6].

\section{E. DHT22}

Sensor DHT22 adalah sensor gabungan dari sensor suhu (temperature) dan kelembaban (humidity) yang outputnya berupa sinyal digital dan tidak membutuhkan komponen tambahan. DHT22 memiliki ukuran yang kecil sehingga mudah digunakan.Gambar 3 merupakan bentuk dari modul DHT22 [7].

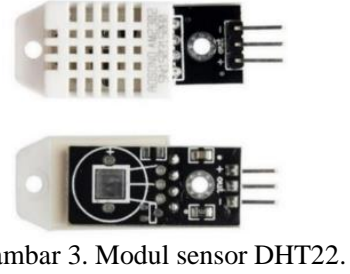

\section{F. Modul Micro SD Card}

Modul micro sd Card merupakan modul untuk mengakses memory card yang bertipe micro SD untuk pembacaan maupun penulisan data dengan menggunakan sistem antarmuka SPI (Serial Parallel Interface). Modul ini cocok untuk berbagai aplikasi yang membutuhkan media penyimpan data, seperti sistem absensi, sistem antrian, maupun sistem aplikasi data logging lainnya [8].

\section{G. GSM Shield}

GSM /GPRS Shield (Gambar 4) adalah modul GSM yang dapat dihubungkan dengan Arduino sehingga memungkinkan Arduino dapat terhubung dengan jaringan seluler GSM. Dengan modul ini, Arduino dapat menerima dan mengirim SMS, melakukan panggilan suara, serta dapat terhubung ke internet dengan menggunakan port koneksi pada GSM/GPRS Shield [9].

\section{H. AT Command}

AT-Command adalah singkatan dari Attention Command. AT Command adalah perintah yang digunakan dalam komunikasi dengan serial port. Salah satu perintah dari ATCommand yakni AT+CSQ. Perintah ini berfungsi untuk melihat kualitas sinyal pada jaringan yang teregistrasi pada perangkat. Hasil tampilan ini adalah +CSQ : <rssi> , <ber>, dimana rssi adalah recived signal strength indication yang memiliki nilai dari 0 sampai 31, 99 jika kekuatan sinyal tidak diketahui atau tidak terdeteksi [10]. RSSI dapat dirubah ke dalam bentuk satuan daya standar yang digunakan untuk mengukur kekuatan sinyal $(\mathrm{dBm})$ dengan persamaan sebagai berikut [11].

$$
d B m=-113+<\operatorname{rssi} \times 2>
$$

\section{Parameter Kualitas Sinyal}

Kekuatan sinyal GSM (2G) ditentukan oleh nilai RSSI yang bernilai negatif. Semakin mendekati 0, maka kekuatan sinyal semakin kuat. Nilai RSSI ini diklasifikan ke dalam beberapa kategori kekuatan sinyal yang ditunjukkan pada Tabel 1 [12].

TABEL I.

\begin{tabular}{lc}
\multicolumn{2}{c}{ KLASIFIKASI KEKUATAN SINYAL PADA HANDPHONE } \\
\hline \multicolumn{1}{c}{ RSSI } & Kekuatan Sinyal \\
\hline$>=-70 \mathrm{dBm}$ & Sangat Baik $($ Excellent $)$ \\
$-70 \mathrm{dBm}$ to $-85 \mathrm{dBm}$ & Baik (Good) \\
$-86 \mathrm{dBm}$ to $-100 \mathrm{dBm}$ & Cukup (Fair) \\
$<-100 \mathrm{dBm}$ & Buruk (Poor) \\
$-110 \mathrm{dBm}$ & No Signal \\
\hline
\end{tabular}

\section{J. Thingspeak}

Thingspeak merupakan Platform Internet of Things yang dapat diintegrasikan dengan Matlab. Pada platform, ini user dapat mengunggah data sensor dari berbagai macam development board yang ada dari hal-hal yang menggunakan HTTP melalui Internet. Data yang di upload pada thingspeak bisa dibuat sebagai data pribadi ataupun data publik. Data tersebut disajikan dalam bentuk channel yang dapat divisualisasikan dan diolah menggunakan software Matlab [13].

\section{PERANCANGAN Sistem}

\section{A. Perancangan Sistem}

Perancangan merupakan tahap yang paling penting dari keseluruhan proses pembuatan suatu perangkat. Perancangan ini dapat dilihat pada Gambar 5 terdiri dari 4 bagian utama yakni:

1. Bagian Sumber daya atau Powersupply perangkat yang terdiri dari dua buah baterai dirangkai seri dan mendapatkan tegangan sekitar 7,2 VDC.

2. Bagian input yang terdiri dari sensor DHT22 untuk mendapatkan data suhu dan kelembaban, serta perangkat anemometer untuk menghitung kecepatan angin.

3. Bagian proses yang terdiri dari mikrokontroler Arduino Uno dengan fungsi untuk mengolah data, melakukan 
perhitungan dan melakukan proses yang menjadi otak dalam perangkat.

4. Bagian output yang terdiri dari penyimpanan data ke micro SD Card, dan pengiriman data hasil proses ke internet menggunakan GSM/GPRS Shield untuk menampilkan ke platform Thingspeak yang telah diprogram untuk menampilkan data hasil proses dari Arduino Uno yang telah ditulis ke micro SD Card dimana dapat langsung diakses oleh pengguna melalui perangkat Interface seperti Laptop yang terhubung ke Internet.

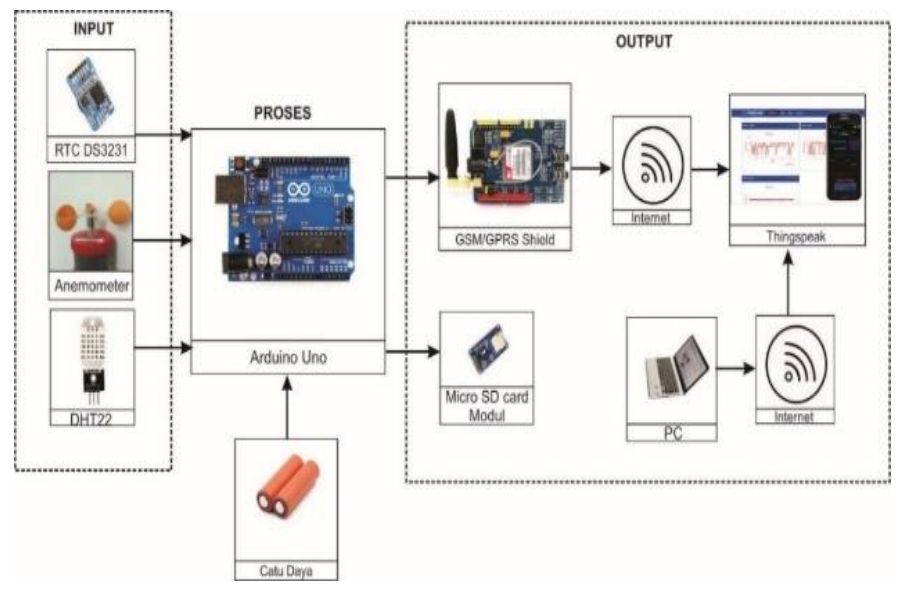

Gambar 4. Diagram blok perancangan perangkat

\section{B. Cara Kerja Sistem}

Proses pada perangkat monitoring yang pertama yaitu inisialisasi sensor DHT22 dan anemometer, modul micro SD Card, RTC, dan GSM Shield SIM900. Proses selanjutnya yakni mendapatkan data sebagai input yang diawali dari proses perekaman data kecepatan angin dari anemometer Dan perekaman data suhu dari sensor DHT22. Data input tersebut diolah di dalam Arduino Uno. Data hasil proses disimpan di micro SD Card. Data juga dikirim ke internet menggunakan SIM900.

Data hasil pengukuran juga dikirimkan melalui Internet ke platform thingspeak dengan memanfaatkan fitur free API untuk mendapatkan menampilkan data output dan fitur free Logging untuk menyimpan hasil data output. Setelah data dikirimkan ke thingspeak, maka untuk melakukan pemantauan data dari perangkat user dapat mengakses thingspeak.com dengan channel yang telah dibuat. Secara ringkas, sistem kerja perangkat ini dapat dilihat pada Gambar 6.

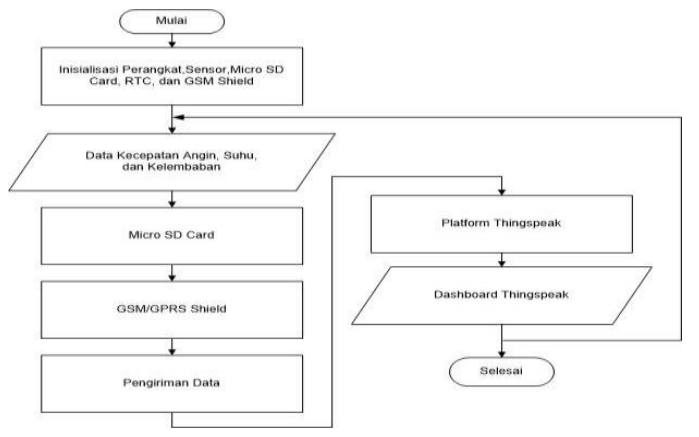

Gambar 5. Diagram alir sistem

\section{Proses Pengujian Sistem}

Proses pengujian dilakukan dengan mehidupkan perangkat yang diujikan pada dua lokasi yang berbeda kualitas sinyalnya. Lokasi pengujian dilakukan di Kelurahan Kampung Bugis, Tanjungpinang dan Jalan Lingkar Wacopek, Bintan. Pengujian dilakukan pada pagi, siang, dan malam hari dan membandingkan rasio penerimaan data pada setiap pengujian

\section{Kualitas Sinyal pada Lokasi Pengujian}

Pengujian kondisi sinyal dilakukan dengan menggunakan perintah AT Command yaitu AT+CSQ. Hasil dari perintah ini ialah nilai dengan rentang dari $0-99$. Nilai tersebut diubah dalam bentuk $\mathrm{dBm}$ dengan persamaan 2. Nilai $\mathrm{dBm}$ ini kemudian diklasifikan ke dalam beberapa kategori kekuatan sinyal [12] yang ditunjukkan pada Tabel 1. Pada lokasi pengujian pertama, kondisi sinyal dapat dilihat dengan menggunakan perintah AT Command dengan menjalankan perintah AT+CSQ. Hasil perintah dari AT+CSQ pada lokasi pengujian pertama dapat dilihat pada Gambar 7 .

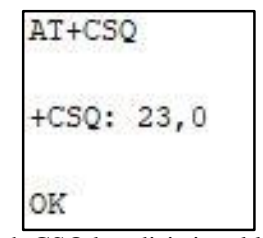

Gambar 6. Hasil perintah CSQ kondisi sinyal lokasi pengujian pertama

Konversi nilai RSSI ini ke dalam dBm memberikan nilai sebesar $-67 \mathrm{dBm}$ yang menunjukkan bahwa sinyal pada lokasi pengujian pertama termasuk dalam kategori sangat baik.

Pada lokasi pengujian kedua, kondisi sinyal dapat dilihat juga dengan menggunakan perintah AT+CSQ dengan hasil yang ditunjukkan pada Gambar 8. Nilai RSSI diperoleh sebesar 13 yang berarti kekuatan sinyalnya sebesar $-87 \mathrm{dBm}$. Nilai dBM ini menunjukkan bahwa kekuatan sinyal pada lokasi Pengujian kedua termasuk dalam kategori cukup.

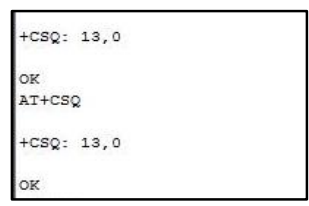

Gambar 7. Perintah CSQ untuk mengetahui kondisi sinyal pengujian kedua

\section{HASIL}

\section{A. Pengujian Sistem pada Lokasi Pertama}

Pengujian keseluruhan pertama ini adalah untuk mengetahui proses pengiriman data. Pengujian ini dilakukan pada pagi hari, siang hari dan malam hari. Sistem telah diintegrasikan dengan micro SD Card sehingga dapat dilihat tingkat keberhasilan pengiriman data. Hasil yang ditunjukkan pada platform Thingspeak berupa tanggal, waktu, jumlah data, suhu, kelembaban, dan kecepatan angin. Jika pengiriman data berhasil, maka data yang ada terekam pada micro SD Card juga akan muncul di dashboard, jika tidak berhasil maka data tersebut hanya ada pada micro $S D$ Card dan tidak akan muncul pada website.

Hasil dari pengujian keseluruhan pertama pada pagi hari dapat dilihat pada Gambar 9 untuk data suhu dan kelembaban 
serta Gambar 10 untuk data kecepatan angin yang tersimpan di dalam micro SD Card. Gambar 11 dan Gambar 12 adalah data dari Thingspeak.

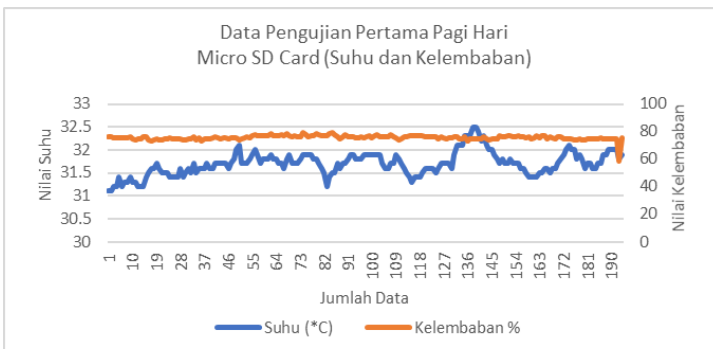

Gambar 8. Grafik data suhu dan kelembaban di micro SD Card pagi hari ke-1

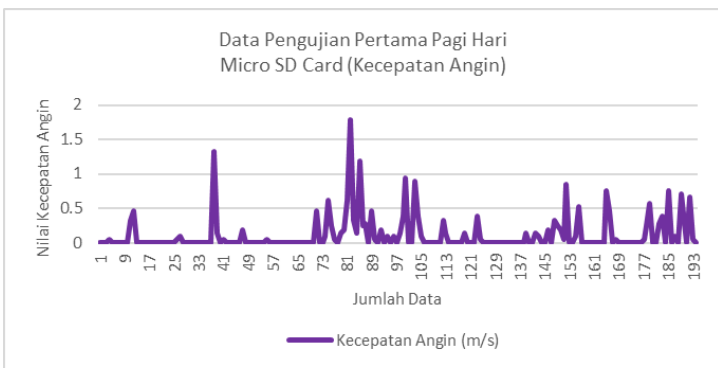

Gambar 9. Grafik data kecepatan angin di micro SD Card pagi hari ke-1

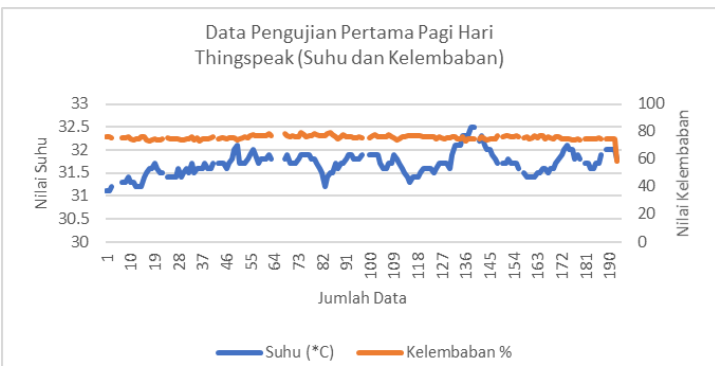

Gambar 10. Grafik data suhu dan kelembaban di Thingspeak pagi hari ke-1

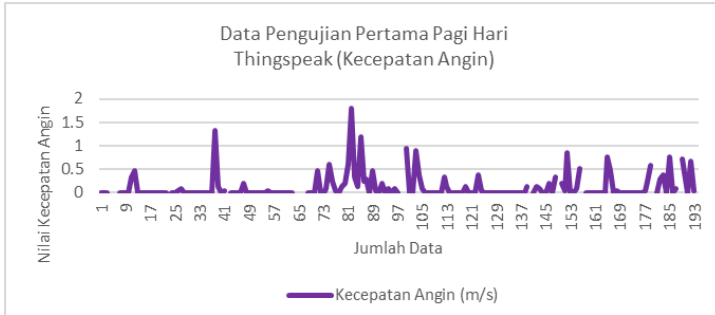

Gambar 11. Grafik data kecepatan angin data di Thingspeak pagi hari ke-1

Pengujian pertama pagi hari didapatkan data sebanyak 194 data yang terekam pada micro SD Card dan 175 data yang tersimpan di Website Thingspeak. Sebanyak 19 data tidak terkirim ke website. Data yang tidak terkirim ini dikarenakan koneksi yang tidak stabil pada GSM/GPRS Shield sehingga data tidak berhasil terkirim ke website. Grafik yang putus-putus pada Gambar 11 dan Gambar 12 menandakan bahwa pada saat tersebut data tidak masuk. Rasio penerimaan data pada website Thingspeak adalah sebesar 90,2 \%. Perbedaan waktu dari RTC dengan waktu yang ada pada website Thingspeak dari data yang sama ialah sebesar 1 menit 10 detik hingga 1 menit 11 detik.

Hasil dari pengujian keseluruhan pertama pada Siang hari dapat dilihat pada Gambar 13 untuk data suhu dan kelembaban serta Gambar 14 untuk data kecepatan angin yang tersimpan di dalam micro SD Card. Gambar 15 dan Gambar 16 adalah data dari Thingspeak.

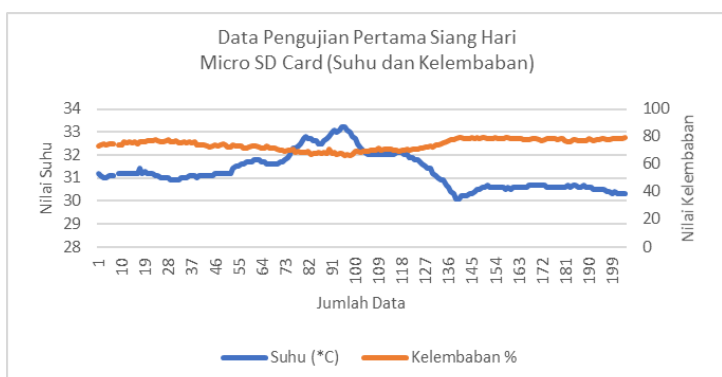

Gambar 12. Grafik data suhu dan kelembaban di Micro SD Card siang hari $\mathrm{Ke}-1$

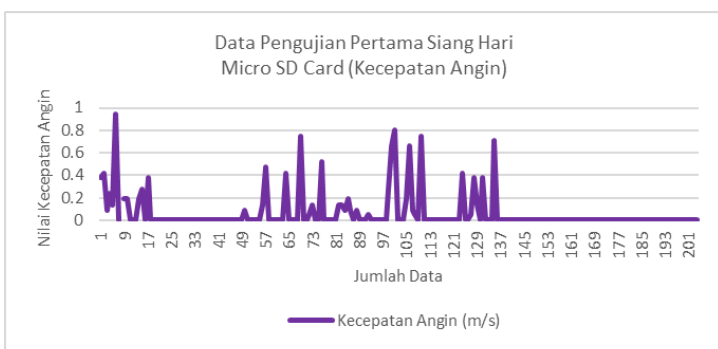

Gambar 13. Grafik data kecepatan angin di micro SD card siang hari ke-1

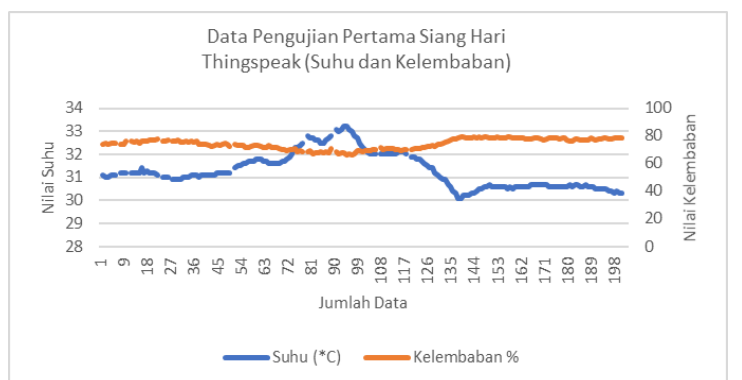

Gambar 14. Grafik data suhu dan kelembaban di Thingspeak siang hari ke-1

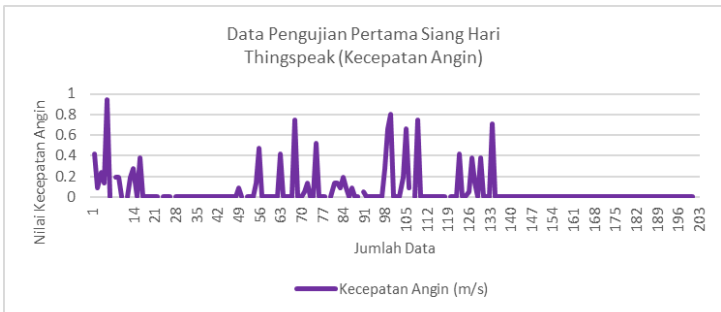

Gambar 15. Grafik data kecepatan angin di Thingspeak siang hari ke-1

Dari pengujian pertama siang hari didapatkan hasil yaitu sebanyak 203 data yang terekam pada micro SD Card dan 192 data yang tersimpan Website Thingspeak sehingga hanya 11 data tidak dapat terkirim ke website. Rasio penerimaan data pada website Thingspeak untuk pengujian pertama Siang hari lebih besar dibandingkan dengan pagi hari yaitu sebesar $94,58 \%$.

Hasil dari pengujian keseluruhan pertama pada Malam hari dapat dilihat pada Gambar 17 untuk data suhu dan kelembaban serta Gambar 18 untuk data kecepatan angin yang tersimpan di dalam micro SD Card. Gambar 19 dan Gambar 20 adalah data dari Thingspeak. 


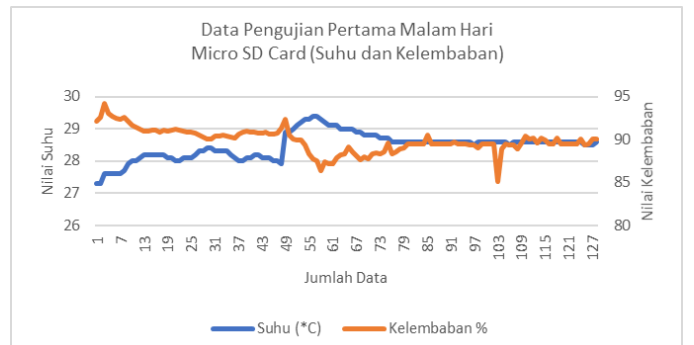

Gambar 16. Grafik data suhu dan kelembaban di Micro SD card malam hari ke-1

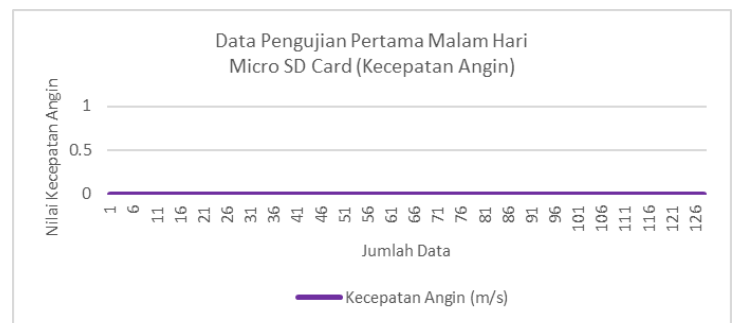

Gambar 17. Grafik data kecepatan angin di micro SD card malam hari ke-1

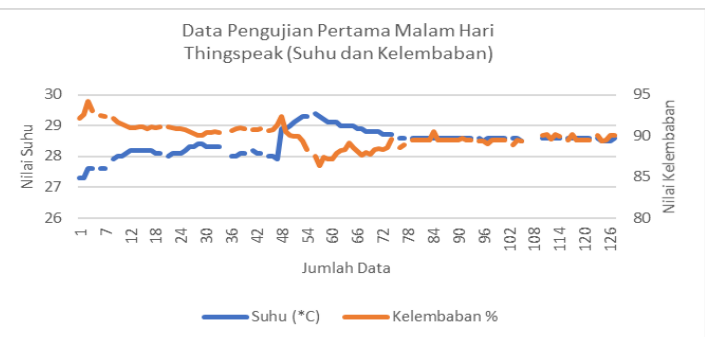

Gambar 18. Grafik data suhu dan kelembaban di Thingspeak malam hari ke-1

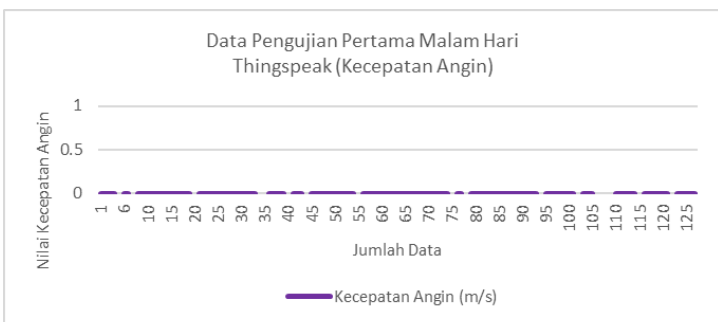

Gambar 19. Grafik data kecepatan angin di Thingspeak malam hari ke-1

Pengujian pertama Malam hari didapatkan data sebanyak 128 data yang terekam pada micro SD Card. Data yang masuk ke Website Thingspeak sebanyak 111 data. Sebanyak 17 data tidak dapat terkirim ke website. Data yang tidak terkirim tersebut dikarenakan koneksi yang tidak stabil pada GSM/GPRS Shield sehingga tidak dapat menyambungkan ke website. Penggunaan micro SD Card sangat penting sekali untuk back up data yang tidak diterima pada Thingspeak. Rasio penerimaan data pada website Thingspeak untuk pengujian pertama malam hari lebih kecil dari dua pengujian sebelumnya yakni sebesar $86,7 \%$. Perbedaan waktu antara RTC dengan waktu yang ada pada website thingspeak yakni sebesar 23 detik hingga 24 detik. Hasil perbedaan waktu ini tidak sama dengan dengan pengujian pagi dan siang dikarenakan RTC diatur waktunya agar bisa mendekati waktu pada platform Thingspeak.

\section{B. Pengujian Sistem pada Lokasi Kedua}

Pengujian keseluruhan kedua adalah untuk mengetahui proses pengiriman data. Pengujian dilakukan pada pagi hari, siang hari dan malam hari pada lokasi yang memiliki sinyal provider yang cukup. Sistem telah diintegrasikan dengan micro SD Card sehingga data dapat melihat tingkat keberhasilan pengiriman data tersebut.

Hasil dari pengujian keseluruhan kedua pada pagi hari dapat dilihat pada Gambar 21 untuk data suhu dan kelembaban serta Gambar 22 untuk data kecepatan angin yang tersimpan di dalam micro SD Card. Gambar 23 dan Gambar 24 adalah data dari Thingspeak .

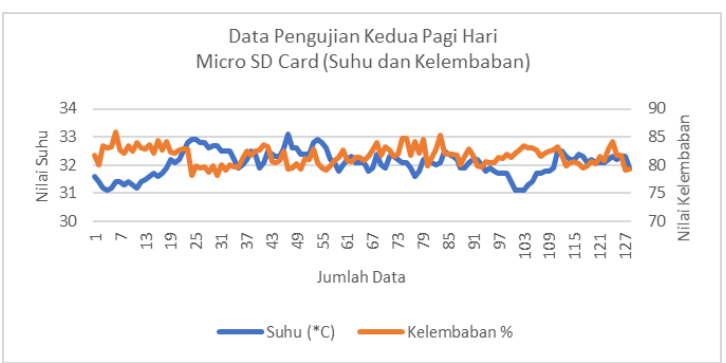

Gambar 20. Grafik data suhu dan kelembaban di micro SD card pagi hari ke-2

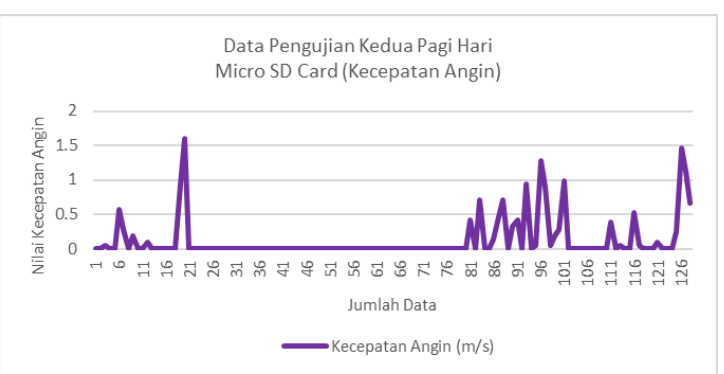

Gambar 21. Grafik data kecepatan angin di micro SD card pagi hari ke-2

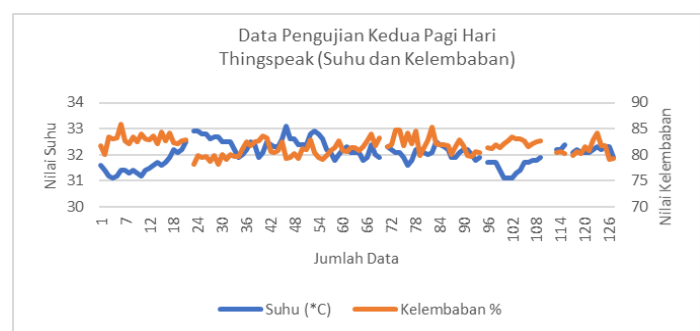

Gambar 22. Grafik data suhu dan kelembaban di Thingspeak pagi hari ke-2

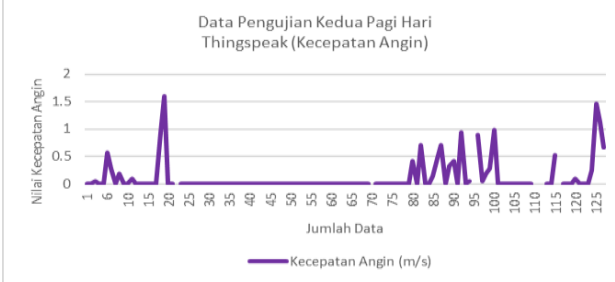

Gambar 23. Grafik data kecepatan angin data di Thingspeak pagi hari ke-2

Pengujian Kedua pagi hari didapatkan data sebanyak 128 data yang terekam pada micro SD Card. Data yang masuk ke Website Thingspeak sebanyak 122 data. Sebanyak 6 data tidak dapat terkirim ke website. Rasio penerimaan data pada website Thingspeak adalah sebesar 95,31\%. Penggunaan RTC yang diatur waktunya secara manual oleh peneliti membuat 
perbedaan waktu antara RTC itu sendiri dengan waktu yang ada pada website thingspeak dengan rata-rata sebesar 23,58 detik.

Hasil dari pengujian keseluruhan kedua pada Siang hari dapat dilihat pada Gambar 25 untuk data suhu dan kelembaban serta Gambar 26 untuk data kecepatan angin yang tersimpan di dalam micro SD Card. Gambar 27 untuk data suhu dan kelembaban dan Gambar 28 untuk data kecepatan angin data dari Thingspeak.

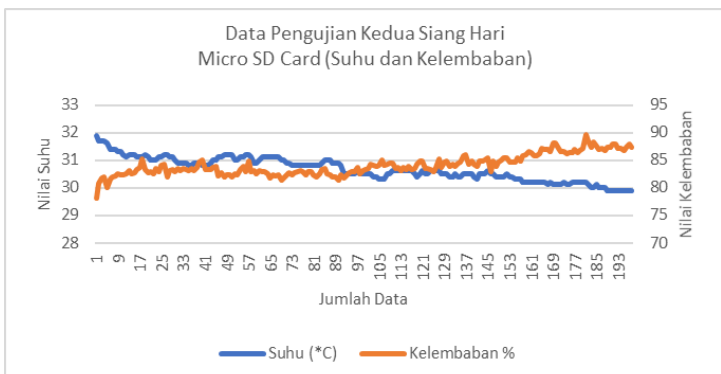

Gambar 24. Grafik data suhu dan kelembaban di Micro SD Card siang hari ke-2

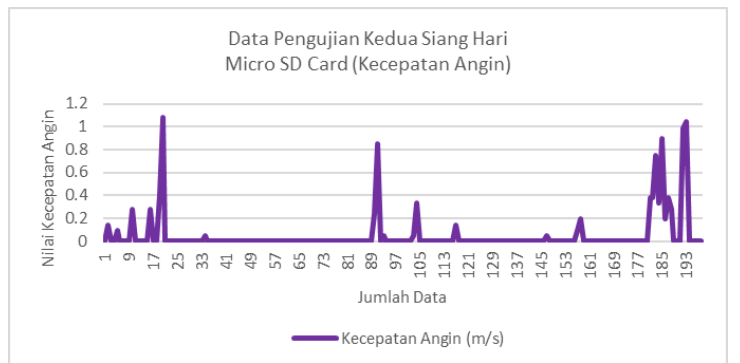

Gambar 25. Grafik data kecepatan angin di micro SD card siang hari ke-2

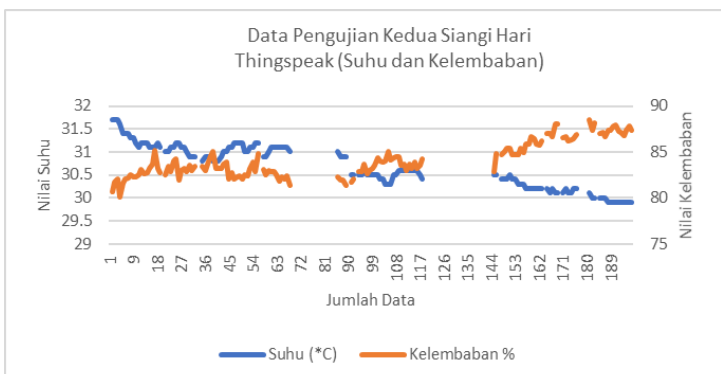

Gambar 26. Grafik data suhu dan kelembaban di Thingspeak siang hari ke-2

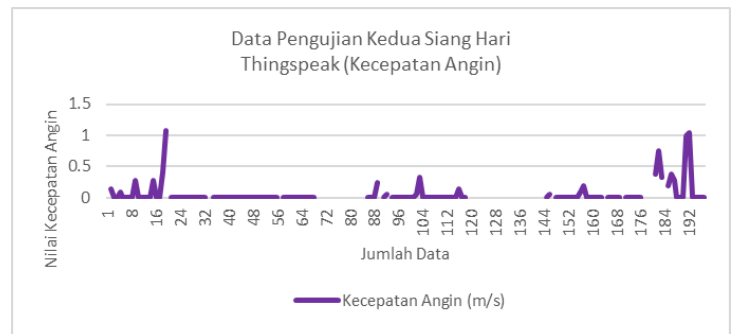

Gambar 27. Grafik data kecepatan angin di Thingspeak siang hari ke-2

Pengujian kedua Siang hari didapatkan data sebanyak 198 data yang terekam pada micro SD Card. Data yang masuk ke Website Thingspeak hanya sebanyak 145 data. Sebanyak 53 data tidak dapat terkirim ke website yang diduga karena koneksi yang tidak stabil pada GSM/GPRS Shield sehingga tidak dapat menyambungkan ke website. Data-data yang tidak masuk tersebut tentu saja mendapat backup yang bagus yakni penyimpanan pada micro SD Card. Rasio penerimaan data pada website Thingspeak untuk pengujian pertama Siang hari adalah sebesar $73,23 \%$.

Hasil dari pengujian keseluruhan kedua pada Malam hari dapat dilihat pada Gambar 29 untuk data suhu dan kelembaban serta Gambar 30 untuk data kecepatan angin yang tersimpan di dalam micro SD Card. Gambar 31 untuk data suhu dan kelembaban dan Gambar 32 untuk data kecepatan angin data dari Thingspeak.

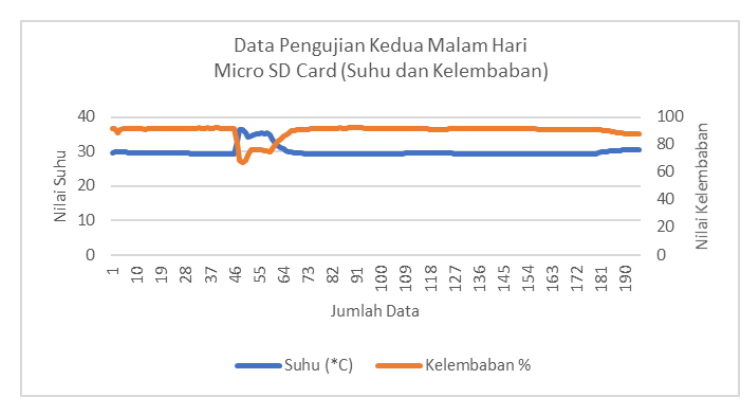

Gambar 28. Grafik data suhu dan kelembaban di Micro SD card malam hari ke-2

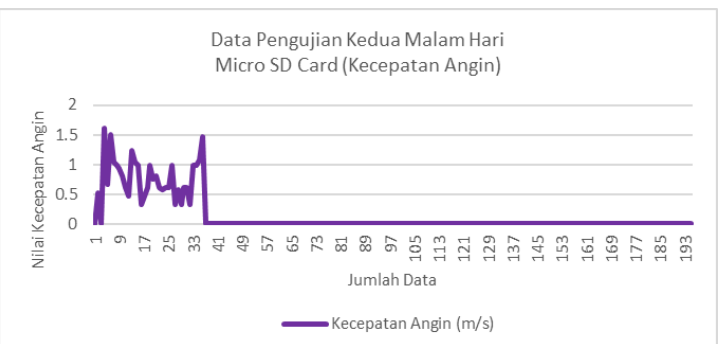

Gambar 29. Grafik data kecepatan angin di micro SD card malam hari ke-2

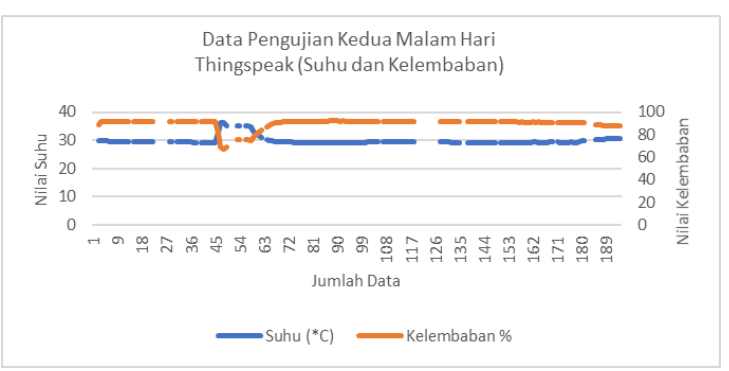

Gambar 30. Grafik data suhu dan kelembaban di Thingspeak malam hari ke-2

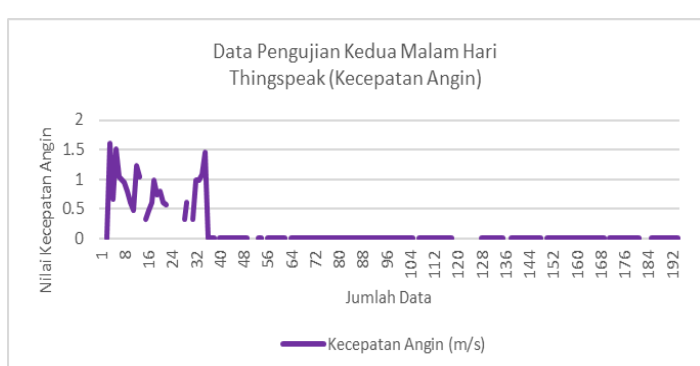

Gambar 31. Grafik data kecepatan angin di Thingspeak malam hari ke-2

Pengujian kedua Malam hari didapatkan data sebanyak 195 data yang terekam pada micro SD Card. Data yang berhasil masuk ke Website Thingspeak sebanyak 166 data. Sebanyak 29 data tidak dapat terkirim ke website. Rasio penerimaan data pada website Thingspeak untuk pengujian pertama malam hari 
adalah sebesar $85,12 \%$.

\section{Perhitungan Konsumsi Daya}

Pada penelitian ini, perhitungan penggunaan konsumsi daya perangkat dibutuhkan untuk mengetahui penggunaan daya untuk pemilihan sumber energi mandiri ke depannya. Berdasarkan hasil pengujian dengan menggunakan multimeter didapatkan konsumsi arus selama 1 jam dengan nilai rata-rata sebesar 0,125 Ah. Pola konsumsi arus perangkat ini ditunjukkan pada 33 yang menampilkan pola arus selama 200 detik yang merepresentasikan pola arus selama 1 jam. Tegangan supply pada perangkat yakni sebesar 7,82 VDC sehingga diperoleh konsumsi daya rata-rata selama 1 jam dapat diperoleh dengan menggunakan persamaan 1 .

$$
\begin{aligned}
& P=7,82 \mathrm{VDC} \times 0,125 \mathrm{Ah} \\
& P=0,977 \mathrm{Wh}
\end{aligned}
$$

Setelah dilakukan perhitungan, maka didapatkan konsumsi daya rata-rata selama 1 jam sebesar 0,977 Wh.

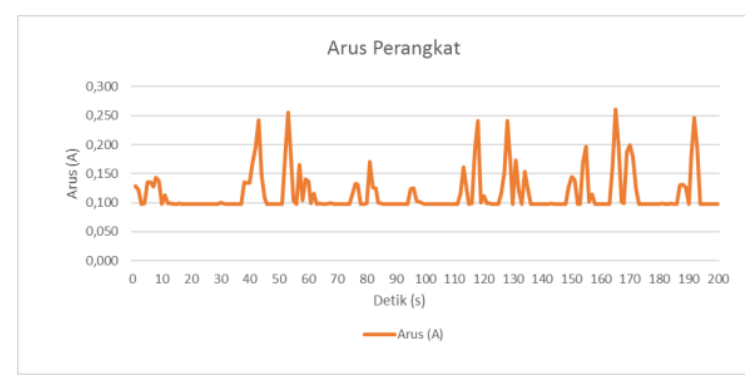

Gambar 32. Grafik pola arus pada perangkat

Perangkat ini menggunakan dua baterai Lithium Ion UR18650A dengan tegangan spesifikasi 3,6 VDC yang diserikan. Tegangan baterai seri diperoleh sebesar 7,2 VDC dengan kapasitas arus sebesar 2,15 Ah, sehingga daya yang dapat dikeluarkan dari dua buah baterai dapat diketahui menggunakan persamaan 1 .

$$
\begin{aligned}
& P=7,2 V D C \times 2,15 A h \\
& P=15,48 W h
\end{aligned}
$$

Setelah diketahui daya yang dapat dikeluarkan baterai sebesar 15,48 Wh. Lamanya waktu perangkat dapat menyala dapat dihitung dengan dengan membagi daya yang dikeluarkan oleh baterai dengan daya dibutuhkan selama 1 jam. Setelah dilakukan perhitungan dapat diperkirakan perangkat ini dapat menyala selama kurang lebih 15,84 Jam.

\section{KESIMPULAN}

Sistem monitoring kecepatan angin, suhu dan kelembaban berbasis website telah berhasil dikembangkan yang dapat mengirim data menggunakan jaringan GSM. Data yang terkirim dapat dilihat pada platform Thingspeak. Data cadangan tersimpan pada micro SD Card. Pada lokasi pertama kondisi sinyal Sangat Baik $(-67 \mathrm{dBm})$ rasio penerimaan data ke website pagi $90,2 \%$, siang $94,58 \%$, dan malam $86,7 \%$. Lokasi kedua kondisi sinyal kategori Cukup $(-87 \mathrm{dBm})$ dengan rasio penerimaan data ke website pagi $95,31 \%$, siang 73,23\%, dan malam $85,12 \%$. Konsumsi daya pada perangkat yang telah dirancang memiliki konsumsi arus selama 1 jam dengan nilai rata-rata sebesar 0,125 Ah dengan tegangan baterai seri sebesar 7,28 VDC sehingga diperoleh konsumsi daya perangkat ratarata selama 1 jam sebesar $0,977 \mathrm{Wh}$. Daya yang dikeluarkan oleh baterai yang digunakan adalah $15,48 \mathrm{Wh}$. Sehingga alat ini diperkirakan dapat bertahan selama 15,8 jam.

\section{REFERENSI}

[1] Suwardi, "Monitoring kecepatan angin berbasis web," Tugas Akhir, Politeknik Negeri Batam, 2017.

[2] S. Andoni dan D. Susanto, "Alat Pengukur Suhu, Kelembaban Relatif, Dan Tekanan Udara Digital," J. Meteorol. Klimatol. Dan Geofis., hlm. 11, 2015.

[3] M. T. Afif dan I. A. P. Pratiwi, "Analisis Perbandingan Baterai LithiumIon, Lithium-Polymer, Lead Acid dan Nickel-Metal Hydride pada Penggunaan Mobil Listrik - Review," J. Rekayasa Mesin, vol. 6, no. 2, hlm. 95-99, Agu 2015.

[4] Technical Learning Collage, Basic Electricity: Continuing Education Professional Development Course. 2018.

[5] M. Banzi dan M. Shiloh, Getting started with Arduino, Third edition. Sebastopol, CA: MakerMedia, 2015.

[6] R. Hidayat dan I. K. Bachtiar, "Perancangan Dan Karakterisasi Prototipe Anemometer Jenis Cup," 2015.

[7] Aosong Electronics Co.,Ltd, "AM2302 Product manual.” Aosong Electronics Co., Ltd, 2012.

[8] A. Faudin, "Cara mengakses module micro SD menggunakan Arduino," nyebarilmu, 2018. .

[9] B. Chaniago dan A. Hamzah, "Analisa dan Desain Monitoring Pembangkit Listrik Tenaga Angin dengan Menggunakan Web dan Arduino," JOM FTEKNIK Univ. Riau, vol. 5, hlm. 6, 2018.

[10] M2MSupport, “AT+CSQ - Signal quality," M2MSupport.net, 28-Apr2012. .

[11] Saptaji, "Mengecek Signal Strength (Kuat Sinyal) Operator dengan AT Command dan Delphi," Saptaji.com, 20-Jan-2013. [Daring]. Tersedia pada: http://saptaji.com/2013/01/20/mengecek-signal-strength-kuatsinyal-operator-dengan-at-command-dan-delphi/. [Diakses: 20-Mei2019].

[12] Teltonika, "Mobile Signal Strength Recommendations," wiki.teltonika.lt, 2019. [Daring]. Tersedia pada: https://wiki.teltonika.lt/view/Mobile_Signal_Strength_Recommendati ons. [Diakses: 02-Jul-2019].

[13] sk.raharja.ac.id, "Thingspeak - CCIT," sk.raharja.ac.id, 2015. [Daring]. Tersedia pada: http://sk.raharja.ac.id/thingspeak/. [Diakses: 16-Okt-2018]. 